\title{
PETROLOGY OF THE SNAP LAKE KIMBERLITE, NWT, CANADA
}

\author{
Trevor Mogg ${ }^{1}$, Maya Kopylova ${ }^{1}$, Barbara Scott Smith $^{2}$, and Melissa Kirkley ${ }^{3}$ \\ ${ }^{1}$ University of British Columbia, Canada $;{ }^{2}$ Scott-Smith Petrology Inc., Canada $;{ }^{3}$ De Beers Canada Mining Inc., Canada
}

\section{INTRODUCTION}

The Snap Lake kimberlite is located $220 \mathrm{~km}$ northeast of Yellowknife in the Northwest Territories. The kimberlite occurs in the southeastern part of the Slave Craton, intruding Archaean granitoids and metavolcanics. The age of the kimberlite is 523 \pm 6.9 Ma. (Geospec Consultants Ltd., 1999). Core drilling shows that the Snap Lake kimberlite consists of a single dominant kimberlite unit that locally splits into several kimberlite units, or 'stringers', that may connect down dip or laterally along strike. The kimberlite sheet dips to the northeast at $\sim 15$ degrees with a minimum plan view area of $2 \times 3 \mathrm{~km}$. The diamondiferous Snap Lake kimberlite is a rare example of a potentially economic, near horizontal sheet-like deposit. The kimberlite has been exposed in two underground sampling tunnels at $124 \mathrm{~m}$ and $164 \mathrm{~m}$ from the present surface. Material from the two tunnels (upper and lower) forms the basis of this petrological investigation. Mapping of the tunnels suggested that the complex is dominated by one main sheet, which has an average thickness of 2 to $3 \mathrm{~m}$. The sheet appears to be composed mainly of hypabyssal kimberlite (Figs. 1 and 2). Associated with the main sheet are two separate, distinct, and volumetrically minor, hypabyssal kimberlite breccias (Figs. 3 and 4). The initial results of the investigation of these phases of kimberlite are presented below.

\section{PETROGRAPHY}

\section{HYPABYSSAL PHLOGOPITE MONTICELLITE KIMBERLITE}

The kimberlite (Fig. 1) in the main sheet is composed of xenolith-poor, coarse to very coarse $(3-20 \mathrm{~mm})$ grained olivine macrocrysts (15-35 modal \%; modal abundances are visual estimates; terminology after Field and Scott Smith, 1998), rare mantle-derived xenocrysts of garnet, olivine phenocrysts ( $<5$ modal \%) and less common phlogopite microphenocrysts set in a groundmass of monticellite, phlogopite, spinel, apatite, perovskite, serpentine and carbonate. The olivine and monticellite have been completely pseudomorphed by serpentine. The kimberlite often has an unusual mega/ macroscopic texture resulting from the presence of common elongate olivine macrocrysts, which are often oriented perpendicular to the sheet contacts, i.e. close to vertical alignment.

Four types of phlogopite, referred to here as Type I to IV, have been recognised petrographically. Phlogopite macrocrysts (Type I) comprise $<1$ modal $\%$ and are large $(0.4-1.5 \mathrm{~mm})$ tabular grains, which typically have resorbed irregular boundaries and display brittle and plastic deformation. Some macrocrysts have thin overgrowths that may, or may not, poikilitically enclose euhedral spinel and monticellite. Occasionally, the grains are zoned with dark brown cores and colourless rims. Phlogopite microphenocrysts (Type II) are tabular to lath-like in shape, have an average length of $0.4 \mathrm{~mm}$, and have inclusion-free cores, and rims which poikilitically enclose spinel and monticellite. Type I and II phlogopites can occur throughout the hypabyssal kimberlite in both the upper and lower tunnels.

The two other texturally and morphologically distinct types of phlogopite, Types III and IV, are present in the groundmass. Type III and IV phlogopites both vary in abundance from 0 to 20 modal \% in different areas of the kimberlite. Type III phlogopite occurs as small (0.1 to $0.3 \mathrm{~mm}$ in length), colourless, late-stage laths with straight and/or irregular step-like boundaries. Some of the Type III grains poikilitically enclose euhedral spinels $(<0.01 \mathrm{~mm})$. Type IV phlogopite occurs as larger $(0.5-0.9 \mathrm{~mm})$, colourless, elongate subhedral laths (Fig. 5). The grain boundaries that parallel the long axis are straight. A characteristic feature of the Type IV phlogopites (Fig. 5) is that they poikilitically enclose relatively common monticellite, spinel and olivine microphenocrysts. This phlogopite typically has a decussate texture. The Type III and IV phlogopites seldom occur in the same sample. Type IV phlogopites appear to occur mainly in the upper sampling tunnel while the Type III phlogopites occur mainly in the lower sampling tunnel.

Other groundmass constituents include 10 to 35 modal $\%$ monticellite, 2 to 5 modal \% spinel, 25 modal \% interstitial carbonate and serpentine as well as accessory apatite and perovskite (Fig. 5). The spinel grains (average size $0.04 \mathrm{~mm}$ ) have a subhedral to euhedral cubic habit; some of the large crystals have an atoll texture. The cores of the spinels are chromite and 
the rims are Ti-magnetite. Apatite typically occurs as interstitial clusters of radially orientated acicular and columnar grains.

The kimberlite is cut by two sets of secondary veins (Fig. 1). One set occurs as well defined white conspicuous, en echelon carbonate veins 0.2 to $3.0 \mathrm{~mm}$ in thickness. These veins are sub-parallel to the contacts of the sheet. The second set of veins are less conspicuous and are light yellowish-grey in colour. The anastomosing veins occur within $30 \mathrm{~cm}$ of the sheet contacts. The dominant constituent of these veins is vermiform serpentine.

Macroscopically, the main kimberlite sheet displays pronounced variations in alteration such as the colour of the olivine macrocryst pseudomorphs and the groundmass (Fig. 1) and in the proportion and type of xenoliths (Figs. 1 and 2). Most areas of the main sheet contain little or no xenolithic material (Fig. 1). In a few contact areas the kimberlite contains common unaltered, bcally derived country rock metavolcanic amphibolite xenoliths (Fig. 2). The variations in macroscopic appearance are likely to be local features related to either alteration or the inclusion of xenoliths adjacent to the contacts. Sharp internal contacts between macroscopically distinct hypabyssal kimberlites have not been observed.

\section{ALTERED HYPABYSSAL KIMBERLITE BRECCIA}

A highly altered breccia (Fig. 3) occurs in three localized areas of the upper tunnel. Mapping of this breccia suggests that it occurs as a sub-horizontal linear tube-like body (basal dimension is $4 \times 4 \mathrm{~m}$ ). There are sharp contacts between the breccia and the main hypabyssal kimberlite. The breccia contains large $(>10 \mathrm{~cm})$ angular amphibolite xenoliths, granitoid xenoliths severely altered by interaction with the host kimberlite (kimberlitised; terminology after Scott Smith et al., 1983), and rare altered eclogite that together form more than 15 modal $\%$ of the rock. The matrix of the breccia is soft, porous, and has a light grayish-green colour. A few olivine macrocrysts can be discerned. Olivine microphenocrysts and phlogopite were not observed. The matrix presently consists of large grains of secondary vermiform serpentine composing (80 modal \%) as well as fine-grained serpentine (10 modal \%) and carbonate (10 modal \%) with accessory spinel. The spinel is probably the only remnant of the original groundmass, which, together with the few discerned olivines, suggests that the matrix of the breccia is altered hypabyssal kimberlite.

\section{HYPABYSSAL GRANITOID-RICH BRECCIA}

A breccia containing abundant granitoid xenoliths (Fig. 4) occurs only in localized areas of the lower tunnel and thus is volumetrically minor. The geometry of the breccia is not well understood but the contacts with the hypabyssal kimb erlite are sharp. The breccia is composed of rounded kimberlitised granitoid country rock xenoliths ( 25 modal \%), abundant feldspar xenocrysts, brown serpentinized olivine macrocrysts (25 modal \%), and 1 modal \% phlogopite microphenocrysts, all set in a reddish brown groundmass. The groundmass contains 10 modal $\%$ of phlogopite, 40 modal \% serpentine, and trace amounts of spinel. The matrix to the breccia differs from the hypabyssal kimberlite in that it is more altered and less common primary constituents are observed, the abundances of olivine macrocrysts and groundmass spinel appear to be lower, the spinels are generally finer grained and atoll textures are not present. The xenoliths have reacted with the kimberlite host and are surrounded by mineralogically complex reaction rims. Thus, the xenoliths must have been resident in the magma for a significant time and, therefore, are likely to have been transported some distance by the kimberlite.

\section{PHLOGOPITE COMPOSITIONS}

The compositions of the Type III and Type IV phlogopites in the hypabyssal kimberlite of the main sheet are presented in Table 1 and Figs. 6 to 8 . The petrographically distinct Type III and IV phlogopites also have contrasting compositions and zoning patterns (Table 1). The two types of phlogopite differ with respect to $\mathrm{TiO}_{2}$ content (Table 1 and Fig. 6). The Type III phlogopite is enriched in $\mathrm{TiO}_{2}, 0.8$ to 2.5 wt.\% versus 0.3 to 0.8 wt. $\% \mathrm{TiO}_{2}$ in Type IV phlogopite. The difference in compositional zoning is particularly evident in the $\mathrm{BaO}$ contents. Type III phlogopite grains show enrichment in $\mathrm{BaO}$ from the cores (mainly $<1.0 \mathrm{wt} . \%$ ) to the rims (mainly 1.5 to $5.0 \mathrm{wt} . \%$; Fig. 7 ). In contrast, the $\mathrm{BaO}$ contents of the Type IV phlogopite grains have $\mathrm{BaO}$-enriched cores (6.5 to $11.0 \mathrm{wt} . \%$ ) with lower $\mathrm{BaO}$ rims (<4.2 wt.\% $\mathrm{BaO}$; Fig. 8). The Type III phlogopite grains also often have high $\mathrm{Cr}_{2} \mathrm{O}_{3}$ cores (up to $1.7 \mathrm{wt} . \%$ ), which do not occur in the Type IV phlogopite grains. 


\section{DISCUSSION}

The Snap Lake sheet complex, as exposed in the two sampling tunnels, is dominated by hypabyssal kimberlite. Petrographic features, supported by matrix mineral and whole rock compositions, show that these rocks can be classified as Group 1 phlogopite monticellite kimberlite. Within the main sheet there are also two volumetrically minor, but distinctly different phases: firstly an altered hypabyssal kimberlite breccia which contains both metavolcanic and granitoid xenoliths and secondly, a hypabyssal granitoid-rich breccia which lacks metavolcanic xenoliths.

The megascopic and macroscopic nature of the main part of the sheet suggests that it comprises a single phase of hypabyssal kimberlite. However, the mode of occurrence and composition of the groundmass phlogopites suggests that this may not be the case. Petrographically contrasting types of phlogopite, Types III and IV, occur in the lower and upper sampling tunnels, respectively. The difference in the nature of the late stage phlogopites suggests that the sheets encountered in the upper and lower sampling tunnels could be separate phases of kimberlite.

The compositions of the Type III and IV phlogopites are different (Fig. 6), which support the petrographic sub-division of the groundmass micas into two types. The zoning within the two types of phlogopite contrast markedly, with Type III having high $\mathrm{BaO}$ rims while the Type IV phlogopites have high $\mathrm{BaO}$ cores. Such contrasting phlogopites are likely to have crystallized from different batches of kimberlite magma. If so, this suggests that the exposures in the upper and lower tunnels could represent different sheets formed by different phases of kimberlite emplacement that underwent contrasting types of magma evolution. Further comparative studies of bulk and mineral compositions of the kimberlites are needed to confirm, or reject, this hypothesis and consider alternative explanations.

The Type III micas, which are common in the lower tunnel, have high $\mathrm{Cr}_{2} \mathrm{O}_{3}$ and $\mathrm{TiO}_{2}$ cores and high $\mathrm{BaO}$ rims. Similar phlogopites have been found in many other kimberlites (Mitchell, 1995). The high $\mathrm{Cr}_{2} \mathrm{O}_{3}$ cores indicate crystallisation at depth, prior to final emplacement. The BaO-rich rims are overgrowths reflecting simple Ba-enrichment during late stage crystallisation and final emplacement. The Type IV phlogopites, on the other hand, display reverse zoning with very high $\mathrm{BaO}$ cores and lower $\mathrm{BaO}$ rims. Such zoning is very unusual but has been observed in kimberlites from Namibia (Mitchell 1995, p. 141). Mitchell (1995) notes that evidence from most kimberlites suggests that there is no such simple trend of Ba-depletion with crystallisation. This shows firstly, that the phlogopites in the upper tunnel are unusual and secondly, that it is difficult to explain their origin.

\section{Table 1: Representative compositions of groundmass phlogopite from the hypabyssal kimberlite}

\begin{tabular}{lrrrr} 
& \multicolumn{1}{c}{ Type III } & Type III & \multicolumn{1}{c}{ Type IV } & Type IV \\
& \multicolumn{1}{c}{ Core } & \multicolumn{1}{c}{ Rim } & \multicolumn{1}{c}{ Core } & \multicolumn{1}{l}{ Rim } \\
$\mathrm{SiO}_{2}$ & 39.35 & 37.39 & 32.35 & 41.23 \\
$\mathrm{TiO}_{2}$ & 1.85 & 1.40 & 0.61 & 0.23 \\
$\mathrm{Al}_{2} \mathrm{O}_{3}$ & 14.39 & 14.52 & 16.84 & 12.77 \\
$\mathrm{Cr}_{2} \mathrm{O}_{3}$ & 1.24 & 0.10 & 0.02 & 0.03 \\
$\mathrm{FeO}$ & 4.07 & 3.88 & 2.88 & 3.23 \\
$\mathrm{MnO}$ & 0.00 & 0.03 & 0.06 & 0.10 \\
$\mathrm{MgO}$ & 24.30 & 24.35 & 23.92 & 26.78 \\
$\mathrm{CaO}$ & 0.00 & 0.02 & 0.03 & 0.05 \\
$\mathrm{BaO}$ & 0.65 & 5.08 & 10.92 & 0.29 \\
$\mathrm{Na} \mathrm{O}_{2} \mathrm{O}$ & 0.05 & 0.06 & 0.06 & 0.02 \\
$\mathrm{~K} \mathrm{O}$ & 10.17 & 8.85 & 6.64 & 10.45 \\
$\mathrm{~F}$ & 0.35 & 1.00 & 1.02 & 0.53 \\
$\mathrm{Cl}$ & 0.03 & 0.02 & 0.02 & 0.07 \\
$\mathrm{Total}$ & 96.45 & 96.70 & 95.37 & 95.78
\end{tabular}

\section{REFERENCES}

Field, M. and Scott Smith, B.H. 1998. Textural and genetic classification schemes for kimberlites: a new perspective. In: Extended Abstracts of the VIIth International Kimberlite Conference, Cape Town. pp $214-216$.

Geospec Consultants Ltd., 1999, Rb-Sr isotopic analysis for Winspear Resources Ltd., De Beers Canada Mining Inc., Unpublished report, June 1999.

Mitchell R.H. 1995. Kimberlites and Orangeites, and Related Rocks. Plenum Press. 410pp.

Scott Smith B.H., Skinner E.M.W. and Clement C.R., 1983, Further data on the occurrence of pectolite in kimberlite. Mineral. Mag. 47, 75-78.

Contact: T.S. Mogg, University of British Columbia, Department of Earth and Ocean Sciences, 6339 Stores Road, Vancouver, BC, Canada, V6T 1Z4

E-mail: tmogg@eos.ubc.ca 


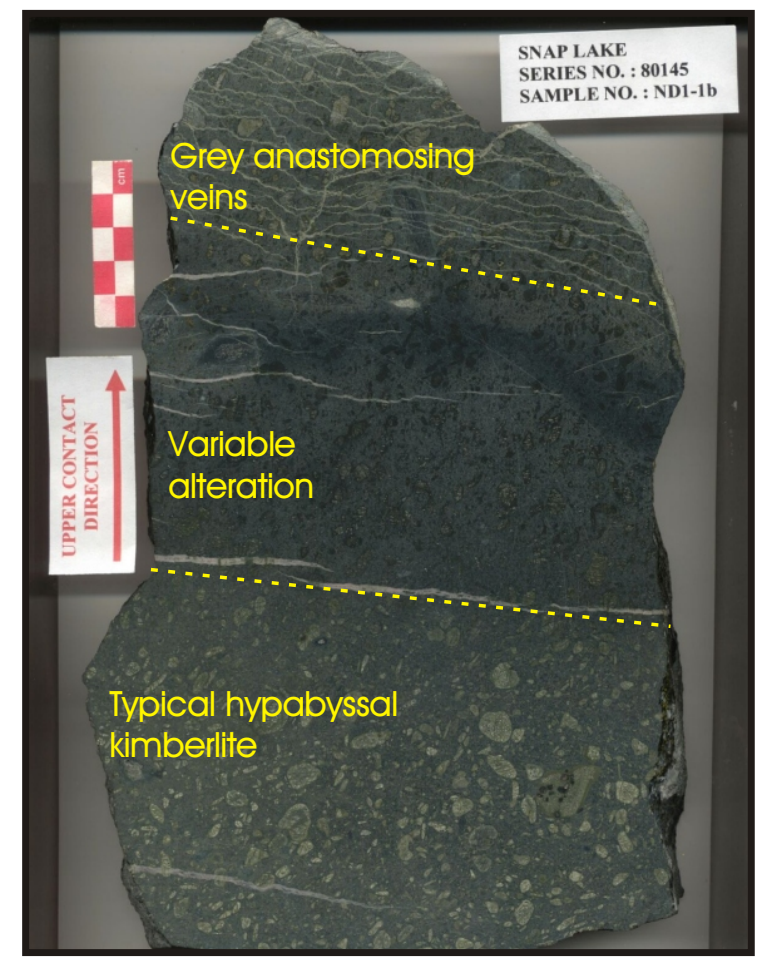

Figure 1: Hypabyssal kimberlite from the upper tunnel. Sample collected adjacent to the upper contact of the main sheet. The bottom of the sample is typical coarse macrocrystic hypabyssal kimberlite and the top of the sample has variable alteration.

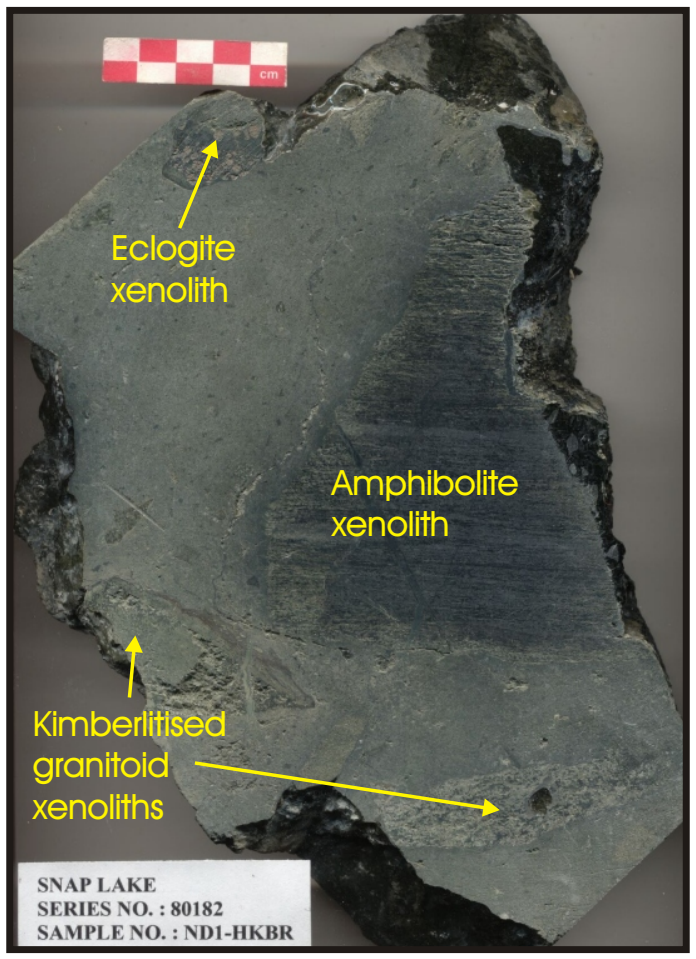

Figure 3: Altered hypabyssal kimberlite breccia from the upper tunnel. The sample contains one large amphibolite xenolith and two kimberlitised granitoid xenoliths. Rare eclogite xenolith occurs near the scale bar.

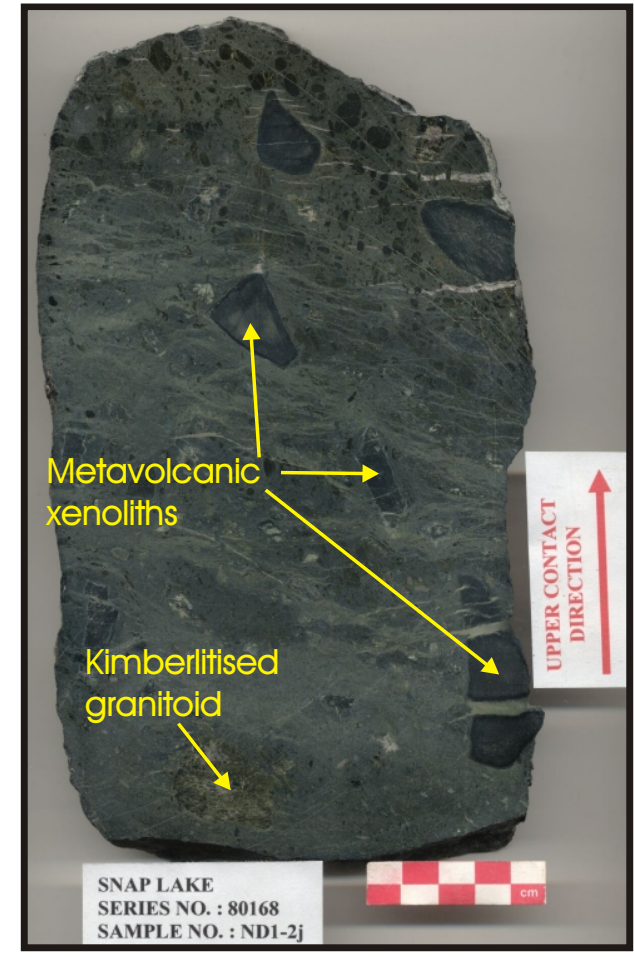

Figure 2: Hypabyssal kimberlite containing common unaltered amphibolite metavolcanic xenoliths and less common kimberlitised granitoid xenoliths. The altered and veined sample was collected adjacent to the lower contact of the main sheet in upper tunnel.

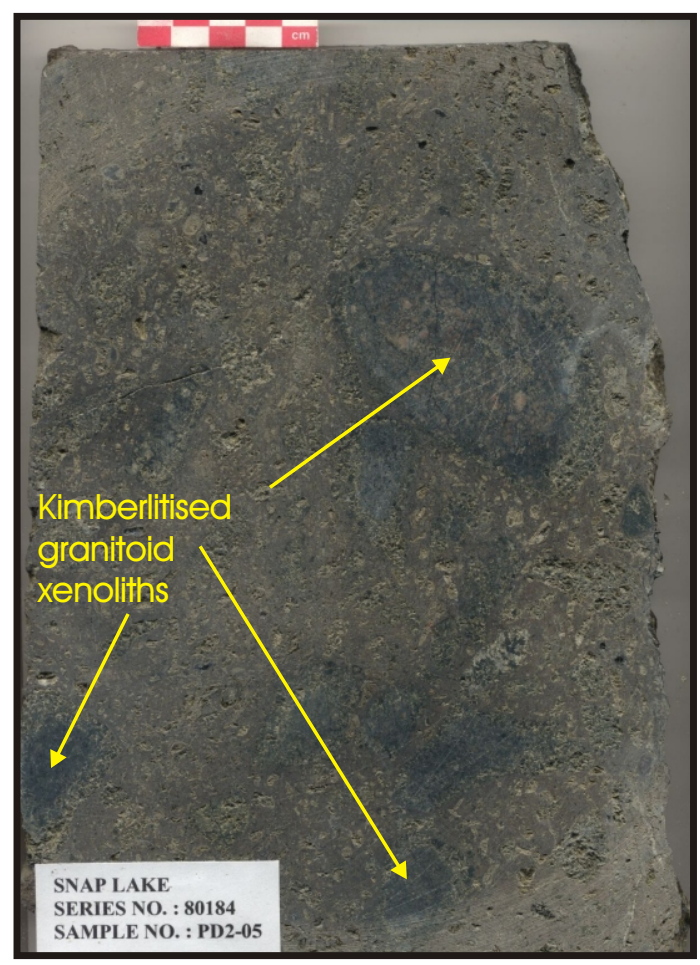

Figure 4: Hypabyssal granitoid-rich breccia from the lower tunnel. The sample contains numerous kimberlitised granitoid xenoliths in an altered brown matrix. 


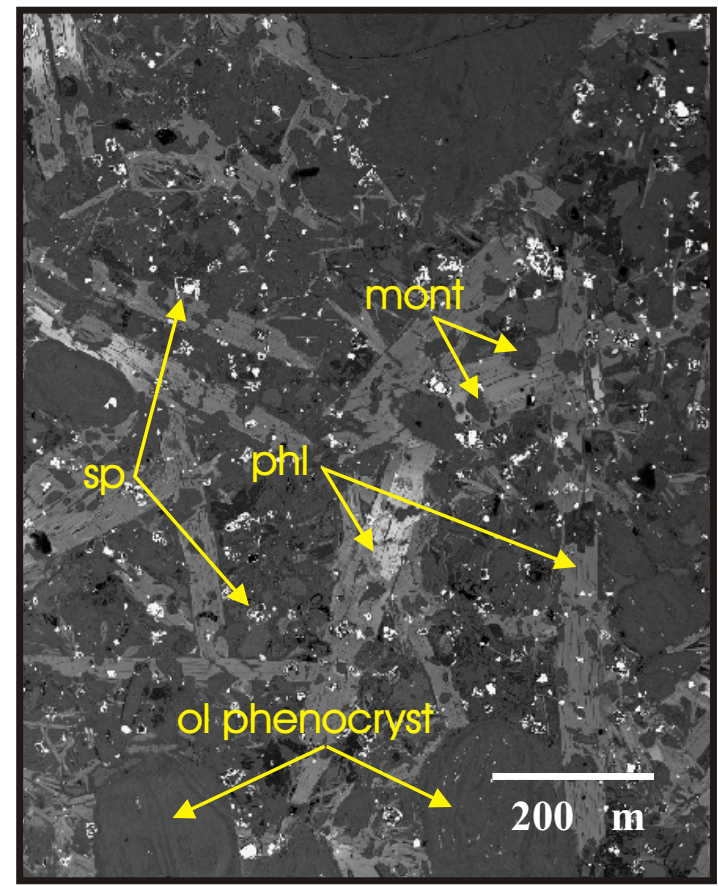

Figure 5: Backscattered electron image of the groundmass in the upper hypabyssal kimberlite with dark grey, euhedral olivine (ol) phenocrysts, small, equant, dark grey, monticellite (mont), and small, bright, euhedral spinel (sp). The larger spinels can have atoll rims. The large light grey, lath-shaped minerals are Type IV phlogopite (phl) grains with inclusions of monticellite, spinel, and olivine phenocrysts. The intergrown laths of phlogopite have random orientation and the brighter areas are enriched in barium.

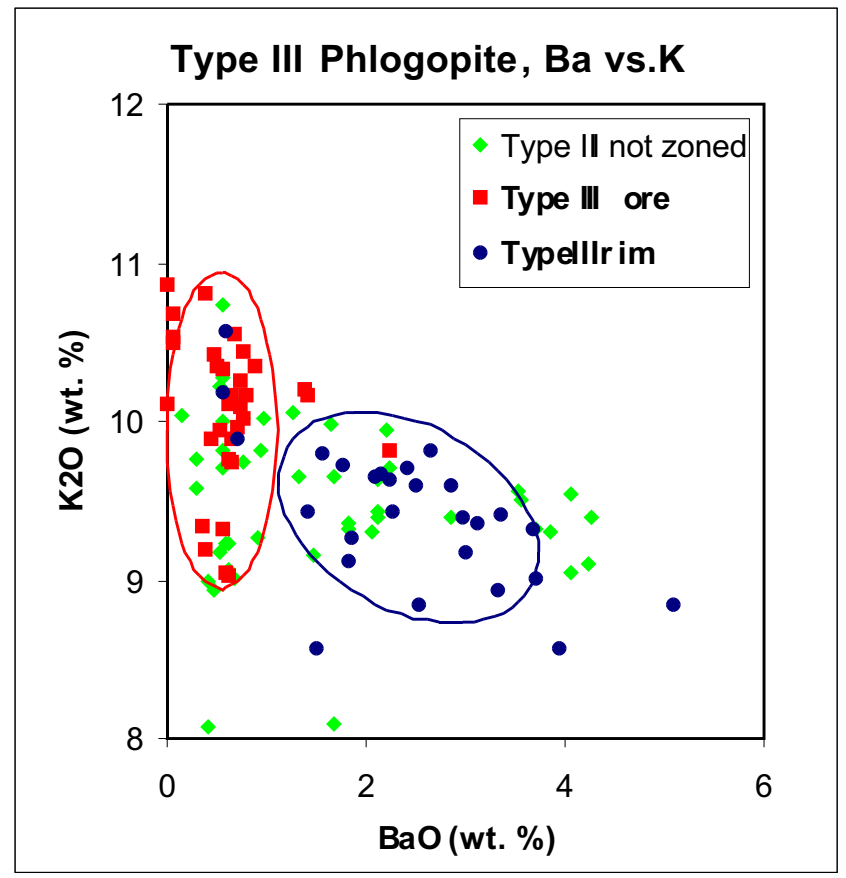

Figure 7: Compositions of Type III groundmass phlogopite. Type III phlogopite shows Ba enrichment from the core to the rim.

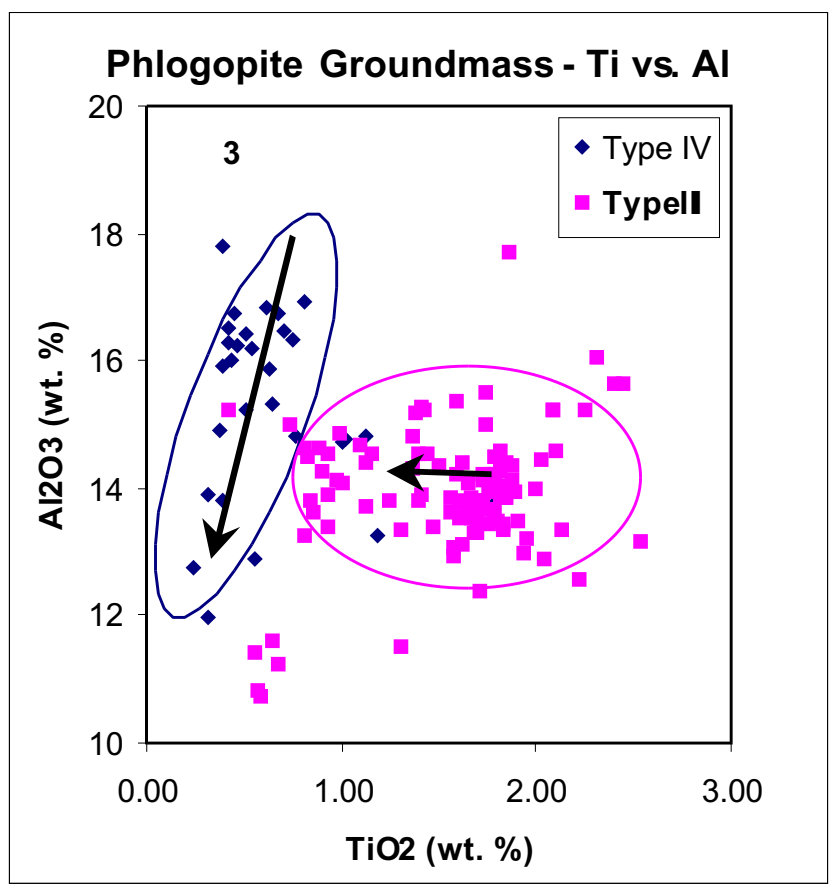

Figure 6: Compositions of Type III and Type IV groundmass phlogopite. Arrows indicate zoning from core to rim.

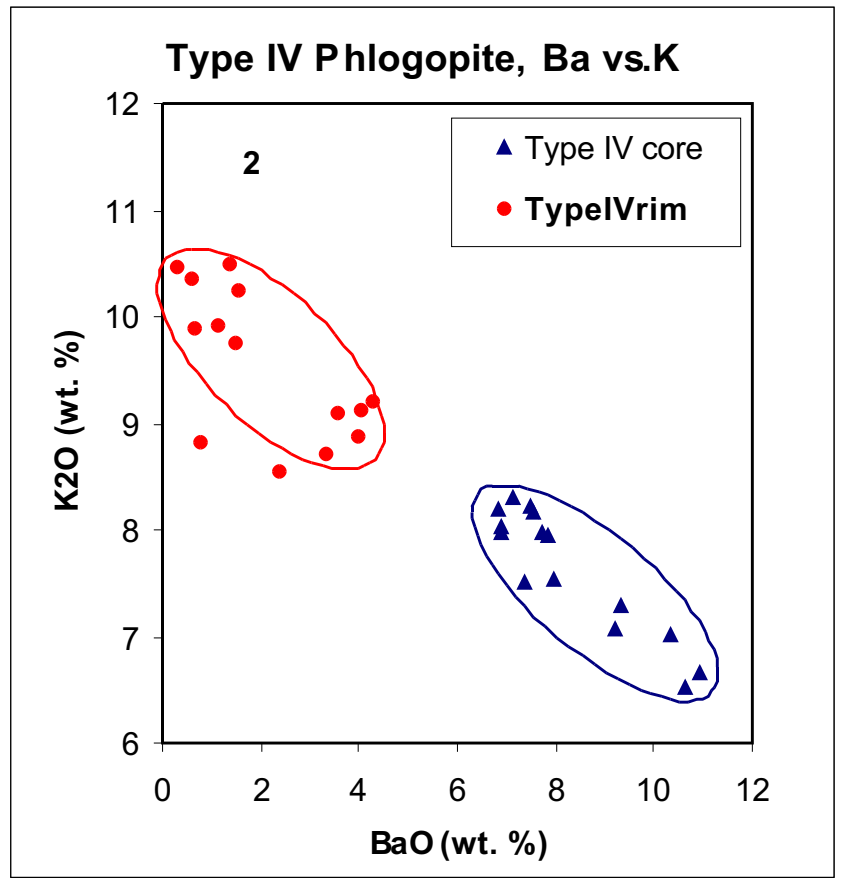

Figure 8: Compositions of Type IV groundmass phlogopite. Type IV phlogopite shows Ba depletion from the core to the rim. 